\title{
POTENTIAL DRUG-DRUG INTERACTIONS AND STRATEGIES FOR THEIR DETECTION AND PREVENTION
}

\author{
MUHAMMAD KASHIF RIAZ ${ }^{1,2 *}$ \\ ${ }^{1}$ University College of Pharmacy, University of the Punjab, Lahore, Pakistan \\ ${ }^{2}$ Pharmaceutics Section, Teaching and Research Division, School of Chinese Medicine, Hong Kong Baptist University, 7 \\ Baptist University Road, Kowloon Tong, Hong Kong
}

*corresponding author: kashifriaz22@yahoo.com

Manuscript received: October 2017

\begin{abstract}
Drugs are often used in combination to achieve a desired therapeutic goal. The concomitant use of drugs may lead to drugdrug interactions (DDIs), which may cause undesired effects in patients. Healthcare professionals should be provided with necessary information about potential drug-drug interaction (pDDIs). The article reviews recent work done on pDDIs, especially in patients with different age groups and co-existing disease conditions. The article also focuses on strategies for the detection of pDDIs and provides information about utilization of these strategies for their prevention.
\end{abstract}

\section{Rezumat}

Medicamentele sunt adesea utilizate în combinație pentru a atinge un scop terapeutic dorit. Utilizarea concomitentă a medicamentelor poate duce la interacțiuni medicamentoase (DDI), care pot provoca efecte nedorite la pacienți. Personalului medical trebuie să li se pună la dispoziție informațiile necesare privind potențialele interacțiuni medicament-medicament (pDDI). Articolul analizează cele mai recente studii publicate în acest sens, în special la pacienți cu diferite grupe de vârstă și comorbidități. Articolul evaluază și strategiile de detectare a pDDI şi oferă informații despre utilizarea acestora în scop preventiv.

Keywords: potential drug-drug interactions; computerized physician order entry; patient safety alerts

\section{Introduction}

Drugs are often used in combination to achieve a required therapeutic goal. The concomitant use of drugs may lead to drug-drug interactions and sometimes may result in undesired effects. The adverse outcomes may be liver damage, kidney damage, haemorrhage and even death to patients. In clinically significant DDIs, modified efficacy or increased adverse effects are observed in patients. It should be remembered that recognizing a potential drugdrug interaction (pDDI) does not mean that the patient will suffer from actual DDI. But the determination of prevalence of pDDIs helps us to identify hazardous pDDIs $[1,2]$. The monitoring of pDDIs may also be helpful in improving the quality of prescribing [3]. In this connection, it should be noted that the prescribers' knowledge of potential clinically significant DDIs is generally inadequate and they underestimate the risk of the concomitant administration of drugs [4]. The occurrence DDIs depends on many factors. The patients that ingest a large number of drugs are in old age or with certain diseases such as renal failures are at high risk for severe drug-drug interactions [5]. In a study, it was found that about 5\% DDIs were present in medication errors (MEs) [6]. In an investigation, it was found that the death of a woman (due to heart arrhythmia) was because of the interaction between citalopram, an anti-anxiety drug, and azithromycin antibiotic. ISMP Canada incident databases and the National System for Incident Reporting was asked to check the data for QT prolongation or arrhythmia involving citalopram or azithromycin (or both) for about 14 years starting from August 1, 2000. Eighteen events which met these criteria were identified and of these, three cases involved a drug interaction between citalopram and azithromycin causing prolonged QT. The 15 cases involved a drug interaction with either azithromycin or citalopram [7]. Further, DDIs also cause an economic burden on patients and health care system. In a study, it was calculated that in the United States (2001), the economic burden of medication-related deaths and illness was over 170 billion dollars [8]. Due to the importance of patient safety, this article has been written. The aim of this review article is to report research work done on potential drug-drug interactions (pDDIs) along with the strategies to detect and prevent these interactions.

\section{Potential drug-drug interaction studies}

A study was carried to find the prevalence of drug-drug interactions in prescriptions which were dispensed 
in both community and hospital pharmacies in Iran. The prescriptions were processed using commercial drug interaction software. Overall, $42 \%$ of prescriptions had at least one pDDI. The percentage of drug interactions in community pharmacies was significantly lower than hospital pharmacies [9]. A study was carried to find the prevalence of pDDI among the patients at the internal medicine ward in Ethiopia. One hundred and eighty four interacting drug combinations with four pDDIs per patient were found. Out of the total pDDIs, $13 \%$ were major interactions. The occurrence of pDDIs was significantly associated with taking three or more drugs [10].

In a study at a medical centre in Solovonia, the patients were tested for drug interactions. It was found that two third of discharged patients had pDDIs [11]. The interaction between OTC drugs and other prescribed drugs was investigated in the prescriptions collected from pharmacies in Karachi, Pakistan. About 4\% interactions were major [12]. In a study, about $4 \%$ of patients visiting the dentist were estimated to have a serious drug interaction due to prescribed drugs [13].

Potential drug-drug interactions in children

The pDDIs in children patients suffering from HIV were studied in Nigeria using two database DDI checkers. The importance of the study lies in the fact that chronic HIV patients were taking three to five antiretroviral (ARV) drugs, concomitantly. The early recognition of DDIs before the administration of such drugs is very important in HIV patients. A difference of about 200 pDDIs between two DDI checkers or softwares was observed. The most interacting dug pairs were nevirapine + artemisinin, nevirapine + fluconazole and zidovudine + fluconazole [14].

In another study, the prevalence of drug interactions between antiretroviral and co-prescribed drugs in HIV infected children in Nigeria was investigated. The cases for 5 years starting from January 2005 were studied. Of the cases reviewed, $67 \%$ patients were at the risk of significant DDIs. Artemisinin based combination therapy was prescribed for over $50 \%$ patients accounting for $40 \%$ of significant DDIs [15]. The pDDIs were studied in prescriptions from the National Health Insurance Database in Taiwan for about 2 million new-borns and infants written during 2000 and it was observed that potential DDIs accounted for about $4 \%$ per prescription. The most significant drug-drug interactions were digoxin + furosemide $(20 \%)$; cisapride + furosemide $(6 \%)$ and cisapride + erythrserved thaomycin (5\%) [16].

Potential drug-drug interactions in elderly population The interactions of ntihypertensive with other drugs in individuals of $\geq 60$ years of age were investigated in Brazil. These were mostly, moderately severe. Of the elderly, more probability of potential drug-drug interactions was observed in those using five or more medicines and those hospitalized in the previous year [17]. A study was undertaken to investigate the potential drug-drug interactions in the internal medicine wards of two hospitals in Pakistan. Of the total 400 patients, $53 \%$ patients received at least one pDDI and their potential adverse effects included damage to liver, bleeding, ototoxicity, poisoning of the kidneys, low blood sugar, high blood sugar, etc. There was a significant association of the occurrence of pDDIs with patients' of $\geq 65$ years, hospital stay of $\geq 6$ days and with $\geq 7$ number of prescribed medications [18]. In a study, the prevalence of pDDIs in out-patient department of a tertiary teaching hospital in India was examined. The prevalence of pDDIs was $83 \%$. The majority of the patients belonged to the age group of $51-60$ years. Aspirin was the most frequently prescribed drug and was also the most frequent drug involved in pDDI. The most common pDDI involved metoprolol and aspirin. The mechanisms of interactions were pharmacokinetic (27\%), pharmacodynamic (69\%) and an unknown mechanism (4\%). It was suggested that the use of electronic decision support tools may help in decreasing the problem of pDDIs [19].

A study was carried out involving ambulatory elderly in Italy using outpatient pharmacy database. A fairly large number of DDIs occurred in the chronic elderly patients. The drug pairs involved in DDIs were warfarin + NSAIDS, simvastatin/lovastatin + amiodarone, and simvastatin/lovastatin + macrolides. The predictors of DDIs were determined. It was found that the odds of exposure were higher for those aged over 75 years and also in those with more chronic conditions. Further, the odds were lower in females than men. For each additional prescribed drug, the risk of exposure increased 1.2 times. It was suggested that these findings should be conveyed to drug prescribers. This may increase their awareness about pDDIs [20]. Another study was made to determine the co-prescribing interacting medications from the same prescriber. A total of approximately 3200 individuals were exposed to at least one pDDI with female over $60 \%$. The same prescriber prescribed both the object and precipitant medication for about $50 \%$ of the pDDIs. The mean number of pDDIs per prescriber over a one year period was 2.5. It was found that many pDDIs were due to same prescriber who reccomended the both interacting drugs [21]. Utilizing the data from 2008 to 2010 period present in a commercial database in the USA, the prevalence of health care costs associated with pDDIs in patients taking long-acting opioid analgesics was investigated. The prevalence of major pDDIs was about $6 \%$ during a ninety day period. The interacting opioids were oxycodone, fentanyl, methadone and codeine. The most common precipitant drugs were fluconazole, diltiazem, clarithromycin and verapamil. The estimated monthly health care costs were about 3300 dollars for pDDI with major cohort or age group [22]. Tragni 
FARMACIA, 2019, Vol. 67, 4

et al. analysed data on prescriptions dispensed during twenty months from January 2004. It was found that over 2 million pDDIs occurred. Twenty seven pairs of interacting drugs were identified from concomitant and co-prescribing medications. The highest rates of prescriptions with pDDIs were for drug pairs containing ACE inhibitors plus NSAIDs. The patients in the study were from 59 to 75 years. A higher exposure of pDDIs was observed for patients with $\geq 65$ years of age, the patients containing a large number of drugs and among warfarin users [23].

Potential drug-drug interactions in patients with coexisting diseases

The occurrence of pDDIs in ICU patients was studied using two interaction databases. Of the 240 patient drug records examined, 457 DDIs were identified. About 25\% interactions were major DDIs. The most commonly drugs involved in interactions were antihypertensive and anticoagulant/antiplatelet. The authors suggested the use of computerized physician order entry (CPOE) and or clinical decision support system (CDSS) at prescribing stage [24]. A study for potential DDIs among the inpatients of a teaching hospital in Southern India was carried. The DDIs were pharmacokinetic (42\%), unknown mechanisms (34\%) and pharmacodynamics $(24 \%)$. The greatest number of drug interactions was for cardiovascular patients along with respiratory disease conditions. The DDIs were moderate (70\%) and minor (28\%) [25].

A study was carried in Canada on patients aged 66 years or older discharged after the treatment of acute myocardial infarction. The interaction between proton pump inhibitor and clopidogrel was studied. Most proton pump inhibitors inhibit the bio-activation of clopidogrel to its active metabolite there by decreasing the blood thinning effect of clopidogrel. It was concluded that such patients were associated with an increased risk of reinfarction [26]. A study was conducted to evaluate pDDI in patients with haemodialysis in Palestine. Univariate analysis showed that the number of pDDIs was related to age of the patient, number of the prescribed drugs and the number of diseases [27].

\section{Strategies for detection and prevention of pDDIs}

Computerized Physician Order Entry CPOE with Clinical Decision Support Systems (CDSSs)

The system allows the generation of a prescription order through the use of a computer, thereby decreasing the errors such as poor and illegible handwriting (a prescribing error). The main reason for the prescriptions to be legible was due to the use of computerized prescription system [28]. Clinical decision support system (CDSS) or clinical decision support (CDS) attempts to improve the physician decisions by alerts, suggestions and reminders. CPOE (also called electronic prescribing system or e-prescribing) with CDSS has the ability to check medication errors, drug-drug interactions and drug allergies. Due to the incentive given by the authorities, 44\% hospitals had such systems by 2012 in the USA [29]. The effectiveness of CPOE was studied. The relevant articles were extracted from three databases. The studies were identified which met the criteria set for pDDIs and MEs. It was found that compared with paper prescription, CPOE produced about 50\% decline in pADEs and MEs [30].

The USA, EU and other countries such as Brazil (through Prosoft, and Lei-de-Informatica and Renuncia Fiscal programs), Saudi Arabia (through e-Health program) favour the use of systems which help to reduce the occurrence of pADEs and the cost of health care. The electronic health record (HER) can be linked with CPOE and CDSS. The systems such as EHR-CPOE-CDSS are commercially available. The major market suppliers are MEDITECH, Zynx Health, Cerner Corporation, McKesson Corporation, and EPIC from the USA [31].

These systems (CPOE) are not without problems. New types of errors appear and mostly operators are not familiar with such issues [32]. The use of patient pictures to reduce CPOE errors has been suggested [33]. CDSS issues a large number of alerts and these may produce "Alert Fatigue" or may produce "CryWolf" effect and can cause delays in work flow. The physician can then either change the prescription or override the alert. The alerts are often overridden without even being read, thereby reducing the CDSS effectiveness [34]. For example, one study reported that most pharmacists over-rode the majority of DDI alerts [35]. CDSS should be adjusted to the specific requirements of a department. It was found that customizing CDSS can help to prevent excessive drug-drug interaction alerts [36] but a balance is needed in this regard. Few alerts have the risk of ignoring harm, while many alerts produce distractions and fatigue for the prescribers [37].

In a study using a commercial CDSS, it was found that the average patient received about 4 alerts, during the mean hospitalization period of about 4 days. It means approximately one alert per day. The alerts received were about moderate DDIs, major DDIs, duplicate alerts, renal adjustment alerts and dose alerts without renal adjustments [38]. In a study, the reason for a large of number of alerts issued by CDSS was investigated. It was noted that some common drug combinations such as aspirin and clopidogrel, atorvastatin and clopidogrel (given to heart patients), insulin and aspirin (given to diabetic patients) are also responsible for DDI alerts [39]. In a study, the ability of clinical decision system (CDS) to detect DDIs was investigated in over sixty Arizona state pharmacies for a period of nine months from December 2008. The results showed that many pharmacy CDS perform less than optimum with respect to identifying clinically relevant DDIs [40]. 
FARMACIA, 2019, Vol. 67, 4

Maharashtra State Pharmacy Council, India has launched "Drug Interaction Checker for Prescription" to detect drug-drug interactions from September, 2014 [41]. Recently, The Micromedex Drug-Reax ${ }^{\circledR}$ system was used to find pDDI from medical charts in chronic kidney disease (CKD) patients admitted in a nephrology unit of a tertiary hospital in Karachi, Pakistan from January 2013 to December 2014. Out of the 209 medical charts, pDDIs were found in almost $79 \%$ of CKD patients [42]. The prevalence of pDDIs in patients was investigated in an Onco-Haematology department in Italy using computerized prescription software having an integrated alarm. It was found that at least one pDDI was present in 53 patients [43].

Nowadays, the studies to determine the occurrence of pDDIs are usually based on the use of drug-drug interaction checker software with built in databases or online drug-drug interaction databases i.e. from www.drugs.com [44]. But some problems with commercial drug-drug interaction checker still exist: 1. the interaction present in one data base may be absent in another database; 2 . sometimes a database describes an interaction as "Major" and at the same time another database describes the interaction as "Moderate".

\section{Alerts}

The alerts are issued to give required information regarding drug safety and pDDIs. The Institute for Safe Medication Practice (USA) issues 5 alerts for health care professionals [45]. ISMP Canada issues patient safety health bulletins [46]. The NHS England patient safety alerts from January 2014 will be issued by the new National Patient Safety Alerting System [47]. NHS England and the Medicines and Healthcare products Regulatory Agency (HRA) jointly issued two patient safety alerts on medication errors and medical devices [48]. Alberta Health Services (AHS) issues alerts about patient safety and have recently issued an alert about two drugs [49]. California Hospital Safety Organization issues patient safety alerts. The subscribers automatically receive alerts via email [50]. Global Patient Safety Alert is a web site that has a collection of alerts, advisories and recommendations about patient safety [51]. The FDA issued a public alert on potential interactions between clopidogrel and the proton pump inhibitor omeprazole in 2009 and desires that the clopidogrel label should be updated indicating that patients should not take this drug together with omeprazole [52]. The new European Union (EU) pharmacovigilance legislation (since July 2012) requires that all adverse drug reactions resulting from medication errors (at the EU level) should be reported to EudraVigilance. This is an EU database of adverse drug reactions and is designed to receive process and support the analysis of data [53].

Education \& Interventions

Kamura et al. 2011 studied the effect of physician interventions in aged patients taking 9 or more drugs.
After the intervention, the mean number of medications per patient decreased [54]. The interventions from doctors and nurses in a teaching hospital in Nepal showed a decrease of incidence of potential DDIs from approximately $50 \%$ to $40 \%$ [55]. In another study, the drug related problems after pharmacist intervention (in HIV patients) decreased from about 5 to 4 per patient in a teaching hospital in Brazil. An average of about 3 interventions per patient was proposed. All the proposed interventions were accepted by physicians [56]. A summary (for educational purposes) of known and potential drug-drug interactions in HIV patients including the recommendations for their prevention is available [57]. Further awareness of the prevalent pDDIs could help practitioners to write better quality of drug prescriptions, thereby, avoiding potential unwanted side effects.

Detection of drug-drug interactions mediated by CYP enzymes

It has been suggested that many drug interactions occur due to the inhibition or induction of the cytochrome P450 enzymes [58]. A thorough understanding of the CYP enzymes and drug transporter proteins has led to software methods which are helpful to predict clinically relevant drug interactions [59]. In a study, the detection of DDIs was made using new cytochrome P450-based software on the medical records of newly admitted patients in a hospital. The cytochrome P450 (CYP) enzymes are human hepatic enzymes that are responsible for the metabolism of drugs. In this study, one hundred patients were present with a mean age of about 82 years using a mean of 12 drugs. Eighty percent of patients had at least one CYP450 based DDI [60].

The formation of a comprehensive database on cytochrome P450 enzymes known as "Super CYP" was reported and this can be used for the prediction of drug-drug interactions. It allows users to enter names of several different drugs and to check interactions between these drugs, but the users also receive alternative drug options. As an example, omeprazole (a proton pump inhibitor) and nebivolol (a betablocker) interact on the CYP level. The result shows that omeprazole has an inhibitory effect on CYP 2D6 while nebivolol is a substrate. To avoid this, omeprazole can be substituted with pantoprazole to get a comparable effect, but pantoprazole uses a different pathway [61].

Detection of DDIs via transporter proteins

According to the FDA, the role of transporter proteins (such a P-glycoprotein, organic anion transporter OATs, organic anion transporting polypeptide OATP) in drug-drug interactions is now being recognized. In drug-drug interactions, inhibition or induction of transport proteins takes place. The examples of transporter-based drug-drug interactions include digoxin/ quinidine and fexofenadine/ ketoconazole [62]. In an attempt to understand the role of transporter proteins 
FARMACIA, 2019, Vol. 67, 4

(substrates) in drug-drug interactions, the role of three (intestinal, hepatic and renal) organs drug transporters was investigated. Drug-drug interactions occur when translocation of a drug is influenced by a second drug. These alterations of transporter function by a second drug can be via inhibition or induction [63]. In order to help the prediction of DDIs, an assay method for human transporters OATP1B1 and OATP1B3 (these represent sites for potential drug-drug interactions because they involved in the hepatic uptake of statin drugs) based on fluorescence has been described [64].

Detection of DDIs by modelling drug interaction profiles

A new method for DDI detection was reported which was based on drug interaction profile fingerprints. Through this DDI predictor, a database (with over 17,000 drug-drug interaction candidates) was provided. This database can be combined with other tools such as pharmacovigilance data analysis to facilitate decision support in DDI detection [65]

\section{Statistical methods used in potential drug-drug interaction studies}

Statistical tests have been used to find the association of potential drug-drug interactions with various factors such as number of drugs, age, hospital stay and disease (cardiovascular disease, diabetes, cancer, HIV, renal disease). The tests utilized in these studies were univariate analysis [66], multivariate analysis [67, 68], logistic regression analysis [18, 23, 68-70], multivariable analysis [71] and chi-square test [72]. Similar, statistical tests have also been used in the studies involving medication errors [73], as depicted by Table I.

\begin{tabular}{|c|c|c|c|}
\hline Test & Aim & Result & Ref \\
\hline $\begin{array}{l}\text { Logistic } \\
\text { regression } \\
\text { analysis }\end{array}$ & $\begin{array}{l}\text { To determine the odds ratio for } \\
\text { specific risk factors of pDDIs i.e., } \\
\text { age, gender, hospital-stay and } \\
\text { number of medications. }\end{array}$ & $\begin{array}{c}\text { There was significant association in the occurrence of pDDIs with } \\
\text { patients' age of } 60 \text { years or more, hospital stay of } 6 \text { days or longer, } \\
\text { and seven or more number of prescribed medications. }\end{array}$ & [18] \\
\hline $\begin{array}{l}\text { Logistic } \\
\text { regression } \\
\text { analysis }\end{array}$ & $\begin{array}{l}\text { To examine the predictors of } \\
\text { potential Drug-Drug Interactions } \\
\text { (pDDIs). }\end{array}$ & $\begin{array}{l}\text { On average, subjects involved in pDDIs received } \geq 10 \text { drugs. The } \\
\text { odds of exposure were more frequently higher for age } \geq 65 \text { years, } \\
\text { males, and those taking a large number of drugs. A substantial } \\
\text { number of clinically important pDDIs were observed, particularly } \\
\text { among warfarin users. }\end{array}$ & [23] \\
\hline $\begin{array}{l}\text { Logistic } \\
\text { regression } \\
\text { analysis }\end{array}$ & $\begin{array}{c}\text { To identify the associated factors } \\
\text { for drug-drug interactions and drug- } \\
\text { disease interactions. }\end{array}$ & $\begin{array}{l}\text { The factors significantly associated with having one or more } \\
\text { potential interactions included: taking } 5 \text { or more medicines, patient } \\
\text { age } 60 \text { years or older and suffering from cardiovascular diseases. }\end{array}$ & [68] \\
\hline $\begin{array}{l}\text { Logistic } \\
\text { regression } \\
\text { analysis }\end{array}$ & $\begin{array}{l}\text { To determine association of pDDIs } \\
\text { with age, gender, hospital stay and } \\
\text { number of drugs. }\end{array}$ & $\begin{array}{l}\text { There was significant association in occurrence of pDDIs with } \\
\text { hospital stay of } 7 \text { days or longer }(\mathrm{p}=0.005) \text { and taking } 7 \text { or more } \\
\operatorname{drugs}(\mathrm{p}<0.001)\end{array}$ & [69] \\
\hline $\begin{array}{l}\text { Logistic } \\
\text { regression } \\
\text { analysis }\end{array}$ & $\begin{array}{c}\text { The incidence of DDI-related ADRs } \\
\text { during the study period was } \\
\text { calculated. }\end{array}$ & $\begin{array}{l}\text { Elderly patients who took five or more drugs had a significantly } \\
\text { higher risk of DDI-related ADRs than patients who took three to } \\
\text { four drugs. No significant difference was found with regard to sex. }\end{array}$ & [70] \\
\hline $\begin{array}{c}\text { Chi-square } \\
\text { test }\end{array}$ & $\begin{array}{l}\text { For comparing the frequency of } \\
\text { errors especially drug-drug } \\
\text { interaction in those prescriptions } \\
\text { having less than } 5 \text { and } \geq 5 \text { drugs. }\end{array}$ & $\begin{array}{c}\text { Significant difference was observed }(\chi 2=52.418, \mathrm{p}<0.05) \text { using } \\
\text { SPSS } 19 \text { for those prescription orders having more than } 5 \text { drugs } \\
\text { with Beta-blockers. }\end{array}$ & {$[72]$} \\
\hline $\begin{array}{c}\text { Univariate } \\
\text { and } \\
\text { multivariate } \\
\text { analyses }\end{array}$ & $\begin{array}{l}\text { To investigate the prevalence of } \\
\text { potential drug-drug interactions } \\
\text { (pDDIs) in patients treated in } \\
\text { primary care. }\end{array}$ & $\begin{array}{l}\text { The number of drugs prescribed was significantly associated with } \\
\text { potential DDIs, with an increasing risk from three to five drugs to } \\
\text { six or more drugs. }\end{array}$ & [66] \\
\hline $\begin{array}{c}\text { Multivariate } \\
\text { analysis }\end{array}$ & $\begin{array}{l}\text { To analyse pDDIs with regard to } \\
\text { severity and clinical implications, } \\
\text { and identify associated factors. }\end{array}$ & $\begin{array}{l}\text { The risk of pDDI was significantly increased among elderly } \\
\text { individuals using six or more medications and in patients with } \\
\text { hypertension, diabetes mellitus or heart problems. }\end{array}$ & [67] \\
\hline
\end{tabular}

\section{Conclusions}

Drug-drug interactions (DDIs) are preventable, if one avoids multiple drug treatment. But this is not possible in most of the scenarios; because the potential benefits over-weigh the risk of the occurrence of DDIs with undesired effects or any alternate suitable treatment i.e. drug combination is unavailable. Nowadays, pDDIs can be easily checked by various commercial computer based drug-drug interaction softwares. Healthcare providers should pay attention to major and moderate DDIs, which may be avoided by prescribing other non-interacting drugs. The health care providers should also keep their knowledge up to date to avoid hazardous DDIs.

\section{Conflict of interest}

The author declares no conflict of interest. 


\section{References}

1. Corie K, Hardmann JG, Mechanisms of drug interactions: pharmacodynamics and pharmacokinetics. Anaest \& Int Care Med., 2014; 15(7): 305-308.

2. Preventable Adverse Drug Reactions: A Focus on Drug Interactions. www.fda.gov/Drugs/Development ApprovalProcess/DevelopmentResources/DrugInter actionsLabeling/ucm110632.

3. Merlo J, Liedholm H, Lindblad U, Bjorck-Linne A, Falt J, Lindberg G, Melander A, Prescriptions with potential drug interactions dispensed at Swedish pharmacies in January 1999: cross sectional study. BMJ., 2001; 323(7310): 427-428.

4. Ko Y, Malon DC, Skrepnek GH, Arnstring EP, Murphy JE, Abarca J, Knowledge of and sources of information for potential drug-drug interactions: a postal survey of US prescribers. Drug Safety, 2008; 31(6): 525-536.

5. Aghajani $\mathrm{MH}$, Sistanizad $\mathrm{MH}$, Abbasinazari $\mathrm{M}$, Ghamsari MA, Ayazkhoo L, Safi O, Potential drugdrug Interactions in Post-CCU of a teaching hospital. Ir J Pharm Res., 2013; 12(1): 243-248.

6. Leape LL, Bates DW, Cullen DJ, Cooper J, Demonaco HJ, Gallivan T, Systems analysis of adverse drug events. ADE Prevention Study Group. JAMA, 1995; 274(1): 35-43.

7. Institute for Safe Medication Practices (ISMP) Canada, ISMP Canada Safety Bulletin, 2014; 14(5), Preventable Death Highlights the Need for Improved Management of Known Drug Interactions www.ismp canada.org/download/safetyBulletins/2014/ISMPC SB20145_KnownDrugInteractions.pdf.

8. Ernst FR, Grizzle AJ, Drug-related morbidity and mortality: updating the cost-of-illness model. $J \mathrm{Am}$ Pharm Assoc. (Wash), 2001; 41: 192-199.

9. Dirin MM, Mousavi S, Afshari AR, Tabrizian K, Ashrafi MH, Potential drug-drug interactions in prescriptions dispensed in community and hospital pharmacies in East of Iran. J Res Pharm Pract., 2014; 3(3): 104-107.

10. Bhagavathula AS, Berhanie A, Tigistu H, Abraham Y, Getachew Y, Khan TM, Prevalence of potential drug-drug interactions among internal medicine ward in University of Gondar Teaching Hospital, Ethiopia. As Pac J Trop Biomed., 2014; 4(Suppl 1): S204-208.

11. Fokter N, Možina MM, Brvar M, Potential drugdrug interactions and admissions due to drug-drug interactions in patients treated in medical departments. Wien Klin Wochenschr., 2010; 122(3): 81-88.

12. Shah S, Naqvi BS, Ale-Zehra, Ali D, Saeed R, Naqvi GR, Quantitative Analysis of Drug-Drug Interactions of OTC Drugs with other Prescribed Drugs Collected from Different Hospitals and Clinics of Karachi, Pakistan. Jord J Pharmaceut Sci., 2011; 4(2): 137-148.

13. Sakaar DS, O'Connors H, Potentially serious drugdrug interactions among community-dwelling older adult dental patients. Oral Path Oral Rad., 2011; 112(2): 153-160.

14. Oshikoya KA, Oreagba IA, Ogunleye OO, Lawal $\mathrm{S}$, Senbanjo IO, Clinically significant interactions between antiretroviral and co-prescribed drugs for HIV-infected children: profiling and comparison of two drug databases. Therap Clinl Risk Manag., 2013; 9: 215-221.

15. Oshikoya KA, Oreagba IA, Lawal S, Awodele D, Ogunleye OO, Senbanjo IO, Potential drug-drug interactions in HIV-infected children on antiretroviral therapy in Lagos, Nigeria. HIV/AIDS - Res Pall Care, 2014; 6: 49-59.

16. Yeh ML, Chang YJ, Yeh SJ, Huang LJ, Yen YT, Wang PY, Potential drug-drug interactions in pediatric outpatient prescriptions for newborns and infants. Comput Meth Progr Biomed., 2014; 113(1): 15-22.

17. Mibielli P, Rozenfeld S, Matos GC, de Acurcio FA, Potential drug-drug interactions among elderly using antihypertensives from the Brazilian List of Essential Medicines. Cad Saude Publica, 2014; 30(9): 19471956.

18. Ismail M, Iqbal Z, Khattak MB, Khan MI, Arsalan H, Javaid A, Potential drug-drug interactions in internal medicine wards in hospital setting in Pakistan. Int $J$ Clin Pharm., 2013; 35(3): 455-462.

19. Patel PS, Rana DA, Suthar JV, Malhorta SD, Patel VJ, A study of potential drug-drug interactions among prescribed drugs in medicine outpatient department of a tertiary teaching hospital. J Basic Clin Pharm., 2014; 5(2): 42-44.

20. Dudash K, Negni G, Baccarini S, Rabinowitz V, Mai $\mathrm{V}$, Significant drug-drug Interactions in the elderly. Value in Health, 2011; 14(3): A7.

21. Malone DC, Hines LE, Brown S, Warholk TL, The incidence of potential drug-drug interactions originating from the same prescriber. Value in Health, 2012; 15(4): A24.

22. Summers K, Pergolizzi J, Ma L, Foster D, Overholser B, Sowinski KK, The prevalence of opioid-related major potential drug-drug interactions and their impact on health Care costs. Value in Health, 2013; 16(3): A12.

23. Tragni E, Casula M, Pieri V, Favato G, Marcobelli A, Trotta MG, Prevalence of the Prescription of Potentially Interacting Drugs. PLoS ONE, 2013; 8(10): e78827.

24. Smithburger PL, Kane-Gill SL, Seybert AL, Drugdrug interactions in the medical intensive care unit: an assessment of frequency, severity and the medications involved. Int J Pharm Pract., 2012; 20(6): 402-408.

25. Kulkarni V, Bora SS, Sirisha S, Saji M, Sundaran S, A study on drug-drug interactions through prescription analysis in a South Indian teaching hospital. Ther Adv Drug Saf., 2013; 4(4): 141-146.

26. Juurlink DN, Gomes T, Szmitko PE, Austin PC, Tu JV, Henry DA, A population-based study of the drug interaction between proton pump inhibitors and clopidogrel. CMAJ, 2009; 189(7): 713-718.

27. Al-Ramahi R, Raddad AR, Rashed AO, Bsharat A, Abu-Ghazaleh D, Yasin E, Shehab O, Evaluation of potential drug- drug interactions among Palestinian hemodialysis patients. BMC Nephrolog., 2016; 17 (96): 1-6.

28. Riaz MK, Hashmi FK, Bukhari NI, Riaz M, Hussain $\mathrm{K}$, Occurrence of Medication Errors and Comparison of Manual and Computerized Prescription Systems in Public Sector Hospitals in Lahore, Pakistan. PLoS ONE, 2014; 9(8): e106080.

29. Desroches CM, Charles D, Furukawa MF, Joshi MS, Kralovec P, Mostashari F, Adoption of electronic health records grows rapidly, but fewer than half of 
FARMACIA, 2019, Vol. 67, 4

US hospitals had at least a basic system in 2012. Health Aff (Millwood), 2013; 32(8): 1478-1485.

30. Nuckols TK, Smith-Spangler C, Morton SC, Asch SM, Patel VM, Anderson LJ, The effectiveness of computerized order entry at reducing preventable adverse drug events and medication errors in hospital settings: a systematic review and meta-analysis. Syst Rev., 2014; 3(56): 1-12.

31. PR Newswire, www.prnewswire.com/news-releases/ clinical-decision-support-system-cdss-market-byproduct-integrated-ehr-cpoe-model-knowledge-basedapplications-drug-allergy-alerts-drug-interactionsdelivery-mode-web-based-cloud-based-componenthardware-so-247591701.html.

32. Campbell EM, Sittig DF, Ash JS, Guappone KP, Dykstra RH, Types of unintended consequences related to computerized provider order entry. $J \mathrm{Am}$ Inform Assoc., 2006; 13: 547-556.

33. Hyman DL, Redmond MD, Kaplan DW, The use of patient pictures and verification screens to reduce computerized provider order entry errors. Pediatrics, 2012; 130: 211-219.

34. Cash JJ, Alert fatigue. Am J Health Syst Pharm., 2009; 66: 2098-2110.

35. Murphy JE, Forrey RA, Desiraju U, Community pharmacists' responses to drug-drug interaction alerts. Am J Health Syst Pharm., 2004; 61: 1484-1487.

36. Smithburger PL, Kane-Gill SL, Seybert AL. Drugdrug interactions in cardiac and cardiothoracic intensive care units: an analysis of patients in an academic medical centre in the US. Drug Saf., 2010; 33: 879-888.

37. Coleman JJ, van der Sijs H, Haefeli WE, Slight SP, McDowell SE, Seidling HM, On the alert: future priorities for alerts in clinical decision support for computerized physician order entry identified from a European workshop. BMC Med Inform Decis Making, 2013; 13: 111.

38. Zenzipe Y, Kurnik D, Markovits N, Ziv M, Shamiss A, Halkin H, Loebstein R, Implementation of a Clinical decision support system for Computerized drug Prescription entries in a large tertiary Care hospital. IMAJ, 2014; 16: 289-294.

39. Horn JR, Hansten PD., Customization of drug interaction software: caution is warranted. 2011; www.pharmacytimes.com/publications/issue/2011/ August2011/Customization-of-Drug-InteractionSoftware\#sthash.pbUDIiRD.dpuf.

40. Saverno KR, Hines LE, Warholak TL, Grizzle AJ, Babits L, Clark C, Ability of pharmacy clinical decisionsupport software to alert users about clinically important drug-drug interactions. J Am Med Inform Assoc., 2011; 18(1): 32-37.

41. Nautiyal S, MSPC launches software to detect drug to drug interactions. 2014; www.pharmabiz.com/News Details.aspx? aid $=83849 \&$ sid $=1$.

42. Saleem A, Masood I, Khan TM, Clinical relevancy and determinants of potential drug-drug interactions in chronic kidney disease patients: results from a retrospective analysis. Integrat Pharm Res Pract., 2017; 6: 71-77.

43. Stefano V, Elena O, Corrado C, Enrico D, Alessandra $\mathrm{R}$, Alessia S, Luigi C, Prevalence study on potential drug-drug interaction in cancer patients in Piacenza hospital's Onco-Haematology department. J Oncol Pharm Pract., 2017; 24(7): 491-493.

44. Banda JM, Callahan A, Winnenburg R, Strasberg HR, Cami A, Reis BY, Vilar S, Hripcsak G, Dumontier M, Shah NH, Feasibility of prioritizing drug-drug-event associations found in electronic health records. Drug Saf., 2016; 39: 45-57.

45. Institute for Safe Medication Practices (ISMP), www.ismp.org; www.ismp.org/faq.asp; www.ismp.org/ newsletters/default.asp; www.ismp.org/NAN/default.asp.

46. ISMP Canada bulletins, www.ismp-canada.org/ ISMPCSafetyBulletins.html.

47. National Health Service (NHS), www.england.nhs. uk/ourwork/patientsafety/psa.

48. National Health Service (NHS), www.england.nhs. uk/2014/03/20/med-devices.

49. Alberta Health Services (AHS), www.albertahealth services.ca, https://ca.finance.yahoo.com/news/albertacontributing-global-patient-safety-174500242.html.

50. California Hospital Safety Organization (CHPSO), www.chpso.org/alerts.

51. Global Patient Safety Alerts, www.globalpatient safetyalerts.com/English/About/Pages/default.aspx.

52. The Society for Cardiovascular Angiography and Interventions (SCAI), www.scai.org/default.aspx.

53. European Medicines Agency (EMA), www.ema.europa. eu/ema; www.ema.europa.eu/ema/index.jsp?curl=pages/ special_topics/general/general_content_000570.jsp.

54. Tamura BK, Bell CL, Lubimir K, Iwasaki WN, Ziegler LA, Masaki KH, Physician Intervention for Medication Reduction in a Nursing Home: The Polypharmacy Outcomes Project. J Am Med DirAssoc., 2011; 12(5): 326-330.

55. Bista D, Saha A, Mishra P, Palaian S, Shankar PR, Impact of educational intervention on the pattern and incidence of potential drug-drug interactions in Nepal. Pharm Pract (Granada), 2009; 7(4): 242-247.

56. de Godoi C, Molino RC, Carnelvale RC, Rodrigues AT, Visacri MB, Moriel P, Impact of pharmacist interventions on drug-related problems and laboratory markers in outpatients with human immunodeficiency virus infection. Ther Clin Risk Manag., 2014; 10: 631-639.

57. National Guideline Clearing House, www.guideline. gov/content.aspx?id=15721.

58. Clinically Significant Drug Interaction with the Cytochrome P450 Enzyme System. http://nursinglink. monster.com/training/articles/320-clinicallysignificant-drug-interaction-with-the-cytochromep450-enzyme-system.

59. Tannenbaum C, Sheehan NL, Understanding and preventing drug-drug and drug-gene interactions. Exp Rev Clin Pharmacol., 2014; 7(4): 533-544.

60. Zakrzewski-Jakubiak H, Doan J, Lamoureux P, Singh D, Turgeon J, Tannenbaum C, Detection and Prevention of Drug-Drug Interactions in the Hospitalized Elderly: Utility of New Cytochrome P450-Based Software. Pharmacotherapy, 2011; 9(6): 461-470.

61. Preissner S, Kroll K, Dunkel M, Senger C, Goldsobel G, Kuzman D, SuperCYP: a comprehensive database on Cytochrome P450 enzymes including a tool for analysis of CYP-drug interactions. Nucleic Acids Res., 2010; 38 (Database issue): D237-D243. 
62. Drug Development and Drug Interactions: Table of Substrates, Inhibitors and Inducers. www.fda.gov/ drugs/developmentapprovalprocess/developmentres ources/druginteractionslabeling/ucm080499.html; www.fda.gov/drugs/developmentapprovalprocess/d evelopmentresources/druginteractionslabeling/ucm 093664.html.

63. Müller F, Fromm MF, Transporter-mediated drugdrug interactions. Pharmacogenomics, 2011; 12(7): 1017-1037.

64. Bednarczyk D, Fluorescence-Based assays for the assessment of drug interaction with the human transporters OATP1B1 and OATP1B3. Anal Biochem., 2010; 405(1): 50-58.

65. Vilar S, Uriarte E, Saltana L, Tatonetti NP, Friedman $\mathrm{C}$, Detection of drug-drug interactions by modelling interaction profile fingerprints. PLoS One, 2013; 8(3): e58321.

66. Teixeira JJV, Crozatti MTL, dos Santos CA, RomanoLieber NS, Potential Drug-Drug Interactions in Prescriptions to Patients over 45 Years of Age in Primary Care, Southern Brazil. PLoS ONE, 2012; 7(10): e47062.

67. Secoli SR, Figueras A, Lebrao ML, de Lima FD, Santros JLF, Risk of potential drug-drug interactions among Brazilian elderly. Drugs \& Aging, 2012; 27(9): 759-770.

68. Dobova (Dubova) SV, Rey-Morales H, del TorresArreola P, Suarez-Ortega M, Potential drug-drug and drug-disease interactions in prescriptions for ambulatory patients over 50 years of age in family medicine clinics in Mexico City. BMC Health Serv Res., 2007; 7: 147.

69. Ismail M, Iqbal Z, Khattak MB, Javaid A, Khan MI, Khan TM, Potential drug-drug interactions in psychiatric ward of a tertiary care hospital: prevalence, levels and association with risk factors. Trop $J$ Pharmaceut Res., 2012; 11(2): 289-296.

70. Obreli-Neto RP, Nobili A, Baldoni AB, Guidoni CM, de Lyra Júnior DP, Pilger D, Adverse drug reactions caused by drug-drug interactions in elderly outpatients: a prospective cohort study. Eur J Clin Pharmacol., 2012; 68(12): 1667-1676.

71. Riechelmann RP, Tannock IF, Wang L, Saad ED, Taback NA, Krzyzanowska MK, Potential drug interactions and duplicate prescriptions among cancer patients. JNCI J Nat Cancer Inst., 2007; 99(8): 592-600.

72. Nesar S, Shoaib MH, Yousaf RI, Rahim N, Muhammad IN, Incidence of medication error associated with the use of beta-blockers in Pakistan. Pak J Pharm Sci., 2014; 27(3): 531-536.

73. Riaz MK, Riaz M, Latif A, Medication errors and strategies for their prevention. Pak J Pharm Sci., 2017; 30(3): 921-928. 